\title{
Patents as an indicator of the future development of individual region
}

\author{
Peter Kubik \\ TARIQ Company s.r.o., Kř́žovnická 86/6, Staré Město, 11000 Praha 1, Czech Republic
}

\begin{abstract}
In today's world full of changes, whether the advent of new technologies that are authoritative and will be a trend for many economic sectors or impact Covid epidemic whose effects are still unaware can be sure that the changes in consumer preferences and aggregate demand and increasingly more competition between the largest economies in geographical terms, all this puts more importance on research and development. It is expected a new impetus in the field of patents that will respond to new impulses from the market.

Monitor the development of patents over the last year in the broader perspective implies growth or decline in individual industries and economies, are interesting differences in the intensity of new know-how even within different regions of the world.
\end{abstract}

\section{Introduction}

The long-term the nature of research and development regarded as an essential element of the economic condition. Patent as an innovative tool is one of the most important elements of creating a competitive advantage in the market. It is protected by legal norms that are implemented in every developed country. The creation of patents is involved in many businesses, such as industrial enterprises, universities, research agencies, technology parks, public research institutes. The issue of patents in individual countries and regions is managed by individual public organizations. These organizations accept individual patents, issue decisions and protect the rights associated with them. They headquarter information on patents, which often offer additional opportunities for their interpretations and may be used for subsequent decisions at different levels of the economy.

\subsection{Theoretical starting points related to patents}

Competitive advantage and competitive position are used to indicate the company's ability to compete with each other. Dynamic and unexpected environment business environment requires companies to be prepared to use innovative and effective competitive strategy to build a competitive advantage in the market. [1] Then have achieved competitive advantage impact on the competitive position of which can be described by the terms of its 
profitability. [2] All these phenomena are under a general term that describes the company's ability to compete in the market. [3]

Investment in intangible assets (patents, know-how, trademarks, designs, software) is still under the pressure of global competition in recent decades, a significant source of competitive advantage. [4]

The term invention is understood to mean a set of activities or processes that lead to a particular discovery. The inventor can register his patent with the Industrial Property Office in each country. A patent is an official document that is awarded by the government of the country. The rights associated with this document allows innovators to prohibit another person to perform certain activities related to the patent without his consent.

What is important is the basic characteristics of the features of a patent or improvement proposal, which include [5,6,7]:

- Novelty - is examined using state of the art at the date when the applicant has the Right of Priority. The Right of Priority is understood the date on which the applicant filed the first application for a given invention, regardless of the country in which the application was filed. To this date, it examines the state of the known technology as the novelty is understood to mean the absolute world novelty,

- Inventiveness - is understood as an activity of the inventor, which reached an invention that could be patentable. The examination of the application analyzes whether the invention is the result of creative activity. When assessing inventive step at the Industrial Property Office tends apply fictional person "expert" with average qualifications and general overview of the art to which the invention was made,

- industrial applicability and technical nature - is understood as the utility of the invention in all areas of the economy, regardless of whether they are industry, agriculture or services.

Due to the historical context of patent law, the issue of intellectual property relatively frequently examined through the collection and processing of statistical data. Patents or inventions are directly regulated by national and international legislative standards are accurately recorded and then the source outputs of varying quality are freely available on the websites of national authorities, such as the Slovak Industrial Property Office of the Slovak Republic or transnational joint authorities, such as a. within the European Union European Patent Office.

There are a large number of studies and surveys in measuring innovation. Along with using the input data, such as spending on research and development and human resources in research, patents have become the most common measure of innovative products in the survey. The aforementioned feature comfortable patents is that they are available relatively exact number of inventions in accordance with various aspects. An addition, patents have been well documented, especially in recent years, thanks to extensive online information that can be conveniently organized into databases. Another advantage of patents that may combine different characteristic indicators. [8,9,10,11]

According to Kucka, the types of patent searches include: [12]

\section{- patent analysis and statistics, \\ - patent monitoring.}

Patent analysis and statistics are methods that address the latest trends in science and technology. Also they allow to identify the possibilities of development in the various fields of science and technology worldwide. These analyzes help to get an overview of the authors and owners patent activity in scientific disciplines for the relevant time period or in the field 
of science and technology, where we can monitor the number of registered and published patent applications and also the number of granted patents for individual years.

Patent analysis and statistics provide important information for research institutions, the company management in decision-making and not least investors. All are made from commercial or non-commercial tools. Patent monitoring can be understood as the continuous collection of information about patents, according to certain attributes such as continuous or obtain information about the status of published applications and granted patents.

Start-ups play an important role in innovation in every region, because applied leadership has a decisive influence on the success or failure of a start-up. Team work and leadership in innovation process are necessary for the success of any start-up. [13,14] The general transformation of the global world creates new opportunities for many countries. For example, the role of some of the constraints on the labor market, such as geographical location, underdevelopment and other similar activities, is declining.[15,16]

A successful innovation process is an important part of the business model, which consists of 4 elements, which are interconnected:

- contribution to customer value,

- profit formula,

- key resources

- $\quad$ key processes. [17]

\subsection{Patent law}

Within the industrial property right it is regarded the protection of inventions as the oldest institute of protection. It was the laws for the protection of inventions and subsequently patents that were among the first to be adopted in modern times.

Patents are the national rights granted by national patent offices. There is no patent, which would be granted protection across the EU. One application for a European patent in the European Patent Office (EPO) provides national protection in European countries chosen by the applicant but must be members of the EPO. International application is simplified under the Patent Cooperation Treaty (PCT). Trademark rights and design can register at national level or at Community level. At Community level, are registered at the Office for Harmonization in the Internal Market, located in Alicante (Spain). These rights are exclusive and apply throughout the EU. [18]

Intellectual property rights are still protected by national laws rather than EU law. Their protection in each EU country separately can be complicated and costly, so further harmonization is needed.

In the Slovak Republic, patents are administered by the Industrial Property Office of the Slovak Republic (Úrad priemyselného vlastníctva Slovenskej republiky). The entire process for patents on their characteristics, the method patenting, use and protection governed by the following legal regulations in force in the Slovak Republic: $[5,6,19]$

- Act no. 435/2001 Z.z. on patents, supplementary protection certificates and on amendments to certain acts,

- Act no. 402/2002 Z.z., amending and supplementing Act no. 435/2001 Z.z.. on patents, supplementary protection certificates and on amendments to certain acts,

- Act no. 84/2007 Z.z.., amending and supplementing Act no. 618/2003 Z.z.. on copyright and rights related to copyright (copyright act) and on amendments to certain acts,

- Act no. 517/2007 Z.z. on utility models and on amendments to certain acts (Article III), 
- Act no. 495/2008 Z.z. on the fee for maintaining the patent, the fee for the maintenance of the European patent with effects for the Slovak Republic and the fee for maintaining the validity of a supplementary protection certificate for medicinal and plant protection products and on amendments to certain laws (Article III)

- Decree no. 223/2002 Z.z., which implements Act no. 435/2001 Z.z. on patents, supplementary protection certificates and on amendment of certain acts.

\section{Objective}

The article aims to provide an overview of the current situation in consumer protection with the aim of improving the position and strengthening consumer protection. The priority is to bring together current measures and challenges to strengthen consumers' rights and interests and thus increase their level of protection.

\section{Results and discussion}

The aim of this section is to present an overview and mapping patents and patent holders in their development and status in the world to compare the differences in the economies of individual regions.

\subsection{Global developments in patents}

Prediction of future economic developments in individual countries and regions is also dependent on innovation activity in the market. The hallmark of innovation activity is the number of patent applications. The high volume of patents for certain time period makes the hypothesis of a healthy and sustainable growth, macroeconomic indicators and good condition of businesses in the market. It also allows a fall in the amount of time to prepare the properly stimulus measures by public authorities to reverse the condition. It is important to know the structure of the applied patent, its characteristics, to know the holder of the patent application. This information is concentrated in national and multinational organizations, which manage patents and create databases.

The World Intellectual Property Organization (WIPO) owns the world's largest patent database. From its databases it is possible to present developments in this area over the last 40 years. [19]

\begin{tabular}{|l|r|}
\hline \multicolumn{1}{|c|}{ Region } & Patent applications \\
\hline Africa & 9596 \\
\hline Asia & 1200024 \\
\hline Europe & 1219399 \\
\hline Latin America & 21620 \\
\hline North America & 1213077 \\
\hline Oceania & 52718 \\
\hline Others & 4507 \\
\hline Total & $\mathbf{3 7 2 0 9 4 1}$ \\
\hline
\end{tabular}

Table 1. Patent applications filed per region, 1978-2018

Source: processed according to [20] 
Since 1978 the number of filed patent applications increases year on year and in 2018 it reached 253,000. In 2009, a decrease of total patent applications, when there was a global economic downturn. A similar course is expected in 2020-2021 due to the Covid epidemic, perhaps larger than in 2009. The reason may be a barrier to work, where many companies used home office and researchers did not have access to many of the tools needed for innovation. Yet in 1978, Europe and North America together accounted for about $88 \%$ of the total administration of patents. In 1995 there was a turning point, the combined market share is decreasing in favor of Asia. In 2009, Asia had a larger volume of patent applications than North America, and in 2010 it overtook Europe, becoming the world's largest patent-pending region. In 2018, more than half of the total number of applications came from a single region - Asia (50.5\%).[20,21,22]

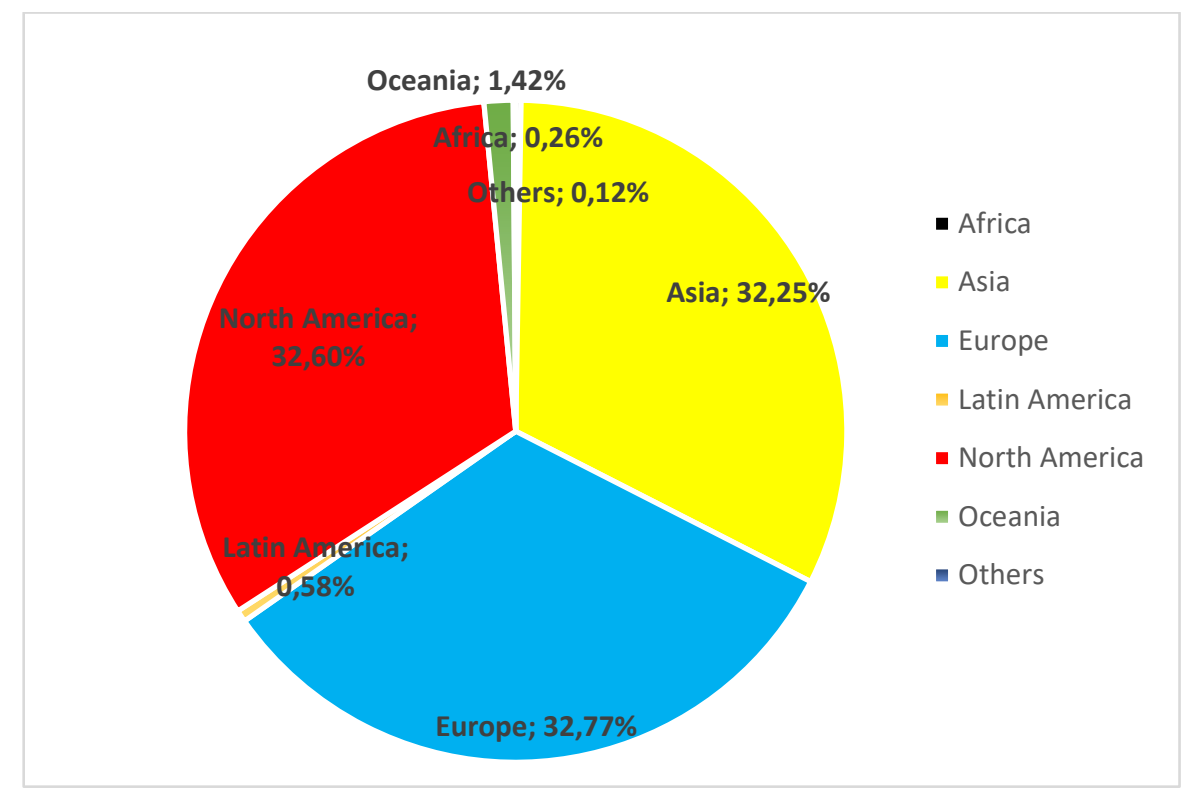

Fig. 1. Region share patent applications for $1978-2018$

Source: processed according to [20]

In the last 40 years, Europe, North America and Asia have applied for patents at about the same volume - Europe $(1,219,399)$ North America $(1,213,077)$ and Asia $(1,200,024)$. These three regions constitute $97.6 \%$ of the total administered in the period 1978-2018. Oceania (52,718), Latin America and the Caribbean (LAC) $(21,620)$ and Africa $(9,596)$ recorded in the same period a much lower volumes. The view of individual countries is also interesting. Applicants for patent applications from the United States of America (USA) have filed $31.1 \%$ of the total number of applications in the last 4 decades. The second largest number of applications was recorded in Japan (17.3\%). If we add the applicants from Germany (10.4\%), China (8.1\%) and the Republic of Korea (4.6\%), the total sum of the top five countries together accounted for $71.4 \%$ of the total number of patent applications during this period.

In 2018, the list of the most successful countries did not change, but their share increased to $77.5 \%$. The largest increase in the proportion of experienced China, which grew from the cumulative $8.1 \%$ over the last 40 years to $21.1 \%$ in 2018 . This is especially remarkable given the fact that between 1978 and 1993 filed by Chinese applicants only five patent applications. 
The majority of applications submitted in Africa between 1978 and 2018 came from South Africa (76.6\%), in Asia by Japan (53.3\%), in North America and Oceania by the USA (95.3\%) and Australia $(86,1 \%)$. Less than half share in the continent achieved the most successful countries in Europe and LAC, where Germany and Brazil represents $31.8 \%$ and $41.6 \%$ of the total. In terms of the nominal number of patent applications for 40 years dominated by the USA $(1,156,062)$, Japan $(641,903)$, Germany $(387,338)$ and China $(303,103) .[20,21,22]$

The view of the Top 30 patent applicants in the world is also interesting:

\begin{tabular}{|c|c|c|c|c|c|c|c|}
\hline \multirow[t]{2}{*}{ Applicant } & \multirow[t]{2}{*}{ Country of Origin } & \multicolumn{2}{|l|}{ Patent applications } & \multicolumn{3}{|c|}{ Ranking in time } & \multirow[b]{2}{*}{2018} \\
\hline & & 1978-2018 & $1978-2018$ & 1990 & 2000 & 2010 & \\
\hline PANASONIC IP MANAGEMENT & Japan & 34081 & 1 & 23 & 6 & 1 & 12 \\
\hline HUAWEI TECHNOLOGIES & China & 33899 & 2 & & 6896 & 4 & 1 \\
\hline KONINKLIJKE PHILIPS ELECTRONICS & Netherland & 32783 & 3 & & 2 & 5 & 18 \\
\hline ROBERT BOSCH CORPORATION & Germany & 27654 & 4 & 2 & 5 & 6 & 10 \\
\hline SIEMENS AKTIENGESELLSCHAFT & Germany & 27403 & 5 & 5 & 1 & 12 & 14 \\
\hline ZTE CORPORATION & China & 25746 & 6 & & & 2 & 5 \\
\hline QUALCOMM INCORPORATED & U.S. & 24858 & 7 & 1510 & 16 & 3 & 4 \\
\hline TELEFONAKTIEBOLAGET LM ERICSSON & Sweden & 22429 & 8 & 98 & 3 & 9 & 9 \\
\hline MITSUBISHI ELECTRIC CORPORATION & Japan & 19342 & 9 & 72 & 19 & 14 & 2 \\
\hline INTEL CORPORATION & U.S. & 17963 & 10 & & 22 & 62 & 3 \\
\hline LG ELECTRONICS INC. & Korea & 17349 & 11 & & 378 & 7 & 8 \\
\hline SHARP KABUSHIKI KAISHA & Japan & 16593 & 12 & 833 & 261 & 8 & 16 \\
\hline SAMSUNG ELECTRONICS & Korea & 15680 & 13 & 1510 & 37 & 17 & 6 \\
\hline 3M INNOVATIVE PROPERTIES COMPANY & U.S. & 14746 & 14 & 195 & 13 & 16 & 30 \\
\hline BASF & Germany & 14654 & 15 & 22 & 7 & 13 & 34 \\
\hline SONY CORPORATION & Japan & 14563 & 16 & 127 & 17 & 28 & 13 \\
\hline TOYOTA JIDOSHA KABUSHIKI KAISHA & Japan & 14201 & 17 & 1510 & 223 & 11 & 236 \\
\hline PROCTER \& GAMBLE COMPANY & U.S. & 13603 & 18 & & 4 & 27 & 36 \\
\hline NEC CORPORATION & Japan & 13282 & 19 & & 122 & 10 & 22 \\
\hline MICROSOFT TECHNOLOGY LICENSING & U.S. & 12870 & 20 & & 30 & 20 & 11 \\
\hline HEWLETT-PACKARD DEVELOPMENT & U.S. & 12095 & 21 & 1510 & 160 & 18 & 15 \\
\hline NOKIA TECHNOLOGIES & Finnland & 11749 & 22 & & 61 & 15 & 35 \\
\hline FUJITSU & Japan & 10049 & 23 & 34 & 27 & 19 & 43 \\
\hline HITACHI & Japan & 9854 & 24 & 84 & 18 & 26 & 27 \\
\hline MOTOROLA & U.S. & 9666 & 25 & 6 & 12 & 116 & 329 \\
\hline E I DU PONT DE NEMOURS & U.S. & 9352 & 26 & 8 & 11 & 21 & 460 \\
\hline FUJIFILM & Japan & 8736 & 27 & & & 48 & 21 \\
\hline UNIVERSITY OF CALIFORNIA & U.S. & 8096 & 28 & 21 & 23 & 38 & 38 \\
\hline INTERNATIONAL BUSINESS MACHINES & U.S. & 7706 & 29 & 195 & 62 & 22 & 100 \\
\hline BOE TECHNOLOGY GROUP & China & 7443 & 30 & & & & 7 \\
\hline
\end{tabular}

Table 2. TOP 30 patent applicants 1978-2018

Source: processed according to [20]

Top 30 patent applicants come from eight countries. On top of the list are the USA with 10 applicants, followed by Japan (9), Germany (3) China (3) South Korea (2), Finland (1), Netherlands (1) Sweden (1). Seven of the 10 best candidates in the last 40 years appeared among the 10 best candidates in 2018. The exception was Panasonic (12th place in 2018), Philips Electronics (18) and Siemens (14). Each active since 197810 best candidates in the electronics industry. [20,21,22] 
List of 30 best covers only businesses, the best university is the University of California (8096) to 38 th place.

\begin{tabular}{|c|c|c|c|c|}
\hline Ranking & University & Origin & $\begin{array}{l}\text { Published } \\
\text { PCT } 2018\end{array}$ & $\begin{array}{c}\text { Ranking All } \\
\text { Applicants }\end{array}$ \\
\hline 1 & UNIVERSITY OF CALIFORNIA & U.S. & 501 & 38 \\
\hline 2 & MASSACHUSETTS INSTITUTE OF TECHNOLOGY & U.S. & 216 & 108 \\
\hline 3 & SHENZHEN UNIVERSITY & China & 201 & 119 \\
\hline 4 & SOUTH CHINA UNIVERSITY OF TECHNOLOGY & China & 170 & 145 \\
\hline 5 & HARVARD UNIVERSITY & U.S. & 169 & 147 \\
\hline 6 & UNIVERSITY OF TEXAS SYSTEM & U.S. & 158 & 158 \\
\hline 7 & SEOUL NATIONAL UNIVERSITY & Korea & 137 & 181 \\
\hline 8 & TSINGHUA UNIVERSITY & China & 137 & 181 \\
\hline 9 & LELAND STANFORD JUNIOR UNIVERSITY & U.S. & 121 & 211 \\
\hline 10 & CHINA UNIVERSITY OF MINING AND TECHNOLOGY & China & 114 & 219 \\
\hline 11 & OSAKA UNIVERSITY & Japan & 105 & 242 \\
\hline 12 & JOHNS HOPKINS UNIVERSITY & U.S. & 99 & 259 \\
\hline 13 & KOREA ADVANCED INSTITUTE OF SCIENCE & Korea & 94 & 273 \\
\hline 14 & UNIVERSITY OF TOKYO & Japan & 92 & 280 \\
\hline 15 & HANYANG UNIVERSITY & Korea & 89 & 294 \\
\hline 16 & TOHOKU UNIVERSITY & Japan & 87 & 300 \\
\hline 17 & KYOTO UNIVERSITY & Japan & 86 & 304 \\
\hline 18 & UNIVERSITY OF MICHIGAN & U.S. & 81 & 324 \\
\hline 19 & OXFORD UNIVERSITY INNOVATION LIMITED & U.K. & 79 & 332 \\
\hline 20 & UNIVERSITY OF FLORIDA & U.S. & 79 & 332 \\
\hline
\end{tabular}

Table 3. TOP 20 patent applicants by universities in 2018

Source: processed according to [20]

\subsection{Patent examination and approval}

The average time duration of the process from application to approval patent in each patent offices varies.

In 2018 the largest national and multinational patent offices needed for the approval process following time period: 


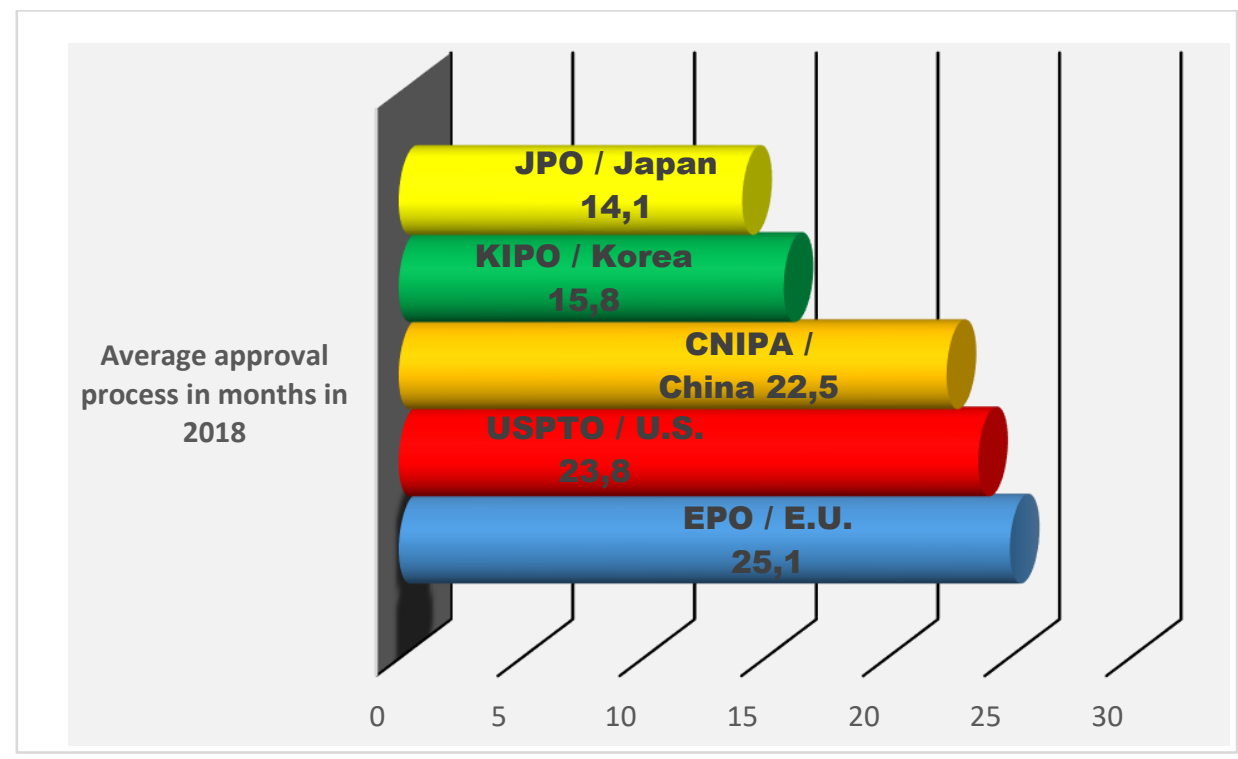

Fig. 2. Average approval process for patents in 2018

Source: processed according to [23]

The time required for the entire patent assessment process is the shortest at the Japan Patent Office (JPO) - 14.1 months. Almost twice as long this process takes at the European Patent Office (25.1 months). All TOP 3 leaders come from Asia.

JPO focuses mainly on accelerating internal processes within its organization. It employs more than 1,400 specialists / examiners who assessed the various patent applications, work closely and actively search for information on patents that are already established in international patent organizations. Speed process, however, must comply with established quality criteria of the organization. [23]

\section{Conclusion}

In the long run, it is clear that innovation efforts are shifting more to Asia. On the contrary, Europe has recently been losing innovation potential, which is very dangerous for its future economic development. The electronic sector is a key accelerator of innovation, which is developing rapidly year by year.

An important factor is also the support of innovation / patents in terms of legislative and approval processes in individual countries. It is certainly motivating for many applicants the shortest possible response to the submitted patent from the patent office. Innovative support from academic institutions is the basis not only for the emergence of new innovative solutions, but also the basis for the education of new innovators. Mentioned attributes should be the minimum for the European Union a major challenge to ensure its future. 


\section{References}

1. S. Farhikhteh, A. Kazemi, A. Shahin, A., M.M. Shafiee. How competitiveness factors propel SMEs to achieve competitive advantage? International Business Journal 1, 2-13 (2020).

2. M. Kharub, R. Sharma 2020, An integrated structural model of QMPs, QMS and firm's performance for competitive positioning in MSMEs. Total Quality Management \& Business Excellence, 31, 3-4 (2020).

3. ]. E. Akben-Selcuk. Factors affecting firm competitiveness: Evidence from an emerging market. International Journal of Financial Studies, 2, 1-10 (2016).

4. Š. Hittmár, M. Hrnčiar, V. Lendel. Management of innovation processes in the enterprise. Žilina: EDIS, p. 15-25 (2017). ISBN 978-80-5541-414-0.

5. M. Kropaj et al. Basics of intellectual property rights for economists. Bratislava: Wolters Kluwer, p. 12-45 (2017). ISBN 978-80-8168-706-8.

6. Z. Adamová. Intellectual property law. Bratislava: TINCT , p. 25-32 (2020). ISBN 97880-9735-440-4.

7. V. Mihálová. The term "plausible" in the decision-making practice of the European Patent Office. Journal Intellectual property, 3, ISSN 1339-5564.

8. B. Hall, A. Jaffe, M. Trajtenberg. The NBER Patent Citations Data File: Lessons, Insights and Methodological Tools. NBER working paper no. 8498 (2001).

9. M. Trajtenberg, G. Shiff, R. Melamed. The "Names Game": Harnessing Inventors' Patent Data for Economic Research, NBER WP no. 12479 (2006), Cambridge, MA.

10. D. Harhoff, K. Hoisl. Institutionalized incentives for ingenuity-patent value and the German Employees' Inventions Act. Research Policy, 36, 1143-1162 (2007).

11. A. Jaffe, M. Trajtenberg, R. Henderson. Geographic localization of knowledge spillovers as evidenced by patent citations. Quarterly Journal of Economics, 63, 577598 (1993).

12. L. Kucka. Types of patent searches - Patent analysis and statistics, patent monitoring. Transfer technológii bulletin. [online]. 2014, Available on the Internet: http://ttb.cvtisr.sk/buxus/docs/ttb_2_2014.pdf, ISSN 1339-2654 [accessed 20.05.2021

13. Zäch, S., Baldegger, U. 2017. Leadership in start-ups. International Small Business Journal: Researching Entrepreneurship, 35, pp. 157-177, ISSN 0266-2426.

14. J. Bussgang. Are you suited for a start-up? Harvard Business Review, 6 (NovemberDecember 2017), 150-153, ISSN 0017-8012.

15. H. Lasi, P. Fettke, H. G. Kemper, T. Feld, M. Hoffmann. Industry 4.0. Business \& Information Systems Engineering, 6, 239-242 (2012), ISSN 2363-7005.

16. K. Ozawa. Managers' experiences as recipients: impact on organizational change. Journal of Organizational Change Management, 33,143-156 (2019), ISSN 0953-4814.

17. M. W. Johnson, C. M. Christensen, H. Kagermann. Reinventing Your Business Model. Harvard Business Review, 86, 2008, ISSN 0017-8012

18. European Patent Office 2021, European Patent Register. [online]. Available on: https://www.epo.org/searching-for-patents/legal/register.html, [accessed 18.05.2021].

19. Industrial Property Office of the Slovak Republic 2021, What are patents. [online]. Available on: https://www.indprop.gov.sk/?co-su-to-patenty, [accessed 18.05.2021].

20. World Intellectual Property Organization 2020, Patent Cooperation Treaty Yearly Review 2020. [online]. Available on:

https://www.wipo.int/edocs/pubdocs/en/wipo_pub_901_2020.pdf, [accessed 20.05.2021].

21. European Patent Office 2021, Patent Index 2020 - European Patent Application. [online]. Available on: 
https://documents.epo.org/projects/babylon/eponet.nsf/0/59B9A0C416D02E75C1258 699004AA62F/\$File/patent_index_2020_european_patent_applications_en.xlsx, [accessed 18.05.2021].

22. United States Patent and Trademark Office 2020, Annual report 2019. [online]. Available on:

https://www.uspto.gov/sites/default/files/documents/PPAC_2019_Annual_Report.pdf, [accessed 18.05.2021].

23. Japan Patent Office 2020, Status report 2020. [online]. Available on: https://www.jpo.go.jp/e/resources/report/statusreport/2020/document/index/all.pdf, [accessed 18.05.2021]. 